\title{
簡便な唾液テストステロン酵素免疫測定
}

\author{
広島大学大学院医歯薬学総合研究科腎泌尿器科 \\ 三田 耕司 松原 昭郎 碓井 亞

\section{MEASUREMENT OF SALIVARY TESTOSTERONE BY A SIMPLE ENZYME IMMUNOASSAY PROCEDURE}

\author{
Koji Mita, Akio Matsubara and Tsuguru Usui \\ Department of Urology, Graduate school of Biomedical Sciences, Hiroshima University
}

(Purpose) The level of serum free testosterone (Se free T) is thought to affect personal emotion and behavior. On the other hand, salivary testosterone (Sa-T) exists mainly in an unbound state and its measurement is noninvasive and repeatable. The aim of this study was to evaluate whether Sa-T can be measured in a clinical setting using a simple enzyme immunoassay kit, and to evaluate whether the level of Sa-T obtained by a simple procedure can be used as a substitute for the level of Se free $\mathrm{T}$ by comparing the values obtained with those of Se free $\mathrm{T}$.

(Patients and Methods) Seventy-six volunteers from among patients who visited our outpatient clinic. They were 74 male and 2 female patients between the ages of 28 and 90 (mean $67.2 \pm 12.7$ years, median 70 years). Sixteen of 74 male patients were treated with hormone therapy for prostate cancer. All of 76 patients were scheduled for blood examinations because of urological diseases, and gave full informed consent to participate in this study. Saliva and serum samples were collected between 06.00 and $11.00 \mathrm{~h}$. Sa-T, Se free $\mathrm{T}$ and the concentration of transferine in saliva was measured with a Salivary Testosterone Enzyme Immunoassay Kit, a Coat-A-Count Free Testosterone and a Blood Contamination Enzyme Immunoassay Kit, respectively. The average of duplicate values was used. Bioavailable testosterone (BT) was assayed by Liquid Chromatography-Mass Spectrometry/ Mass Spectrometry. Average intraassay coefficient of variations of all assays were within 15\%.

(Results) Eleven out of 76 salivary samples were disqualified as unsuitable because of possible blood contamination or falling outside the range of the assay sensitivity. The ranges of Sa-T, Se free $\mathrm{T}$ and the transferrin concentration in saliva were 32 to $360 \mathrm{pg} / \mathrm{ml}(\mathrm{n}=65$, mean $176.8 \pm 96.6 \mathrm{pg} / \mathrm{ml}$, median $168.0 \mathrm{pg} / \mathrm{ml}), 0.15$ to $21.0 \mathrm{pg} / \mathrm{ml} \quad(\mathrm{n}=76$, mean $6.6 \pm 4.2 \mathrm{pg} / \mathrm{ml}$, median $7.0 \mathrm{pg} / \mathrm{ml}$ ), and 0.08 to $6.0 \mathrm{mg} / \mathrm{dl} \quad(\mathrm{n}=76$, mean $0.66 \pm 0.89 \mathrm{pg} / \mathrm{ml}$ median $0.42 \mathrm{mg} / \mathrm{dl})$, respectively. In 10 participants randomized chosen out of all, there was significantly correlation between Se free $\mathrm{T}$ and BT $(r=0.964$, $\mathrm{p}<0.01)$. There was significant correlation between Se free $\mathrm{T}$ and $\mathrm{Sa}-\mathrm{T}(\mathrm{n}=65, \mathrm{r}=0.592, \mathrm{p}<0.01)$ and estimated Se free $\mathrm{T}$ value can be calculated based on the Sa-T level.

(Conclusion) Though disqualified samples accounted for $14.5 \%$ of the total number of saliva samples, Sa-T can be used as a substitute parameter for biologically active testosterone.

Key words : Saliva, Testosterone, Enzyme immunoassay

要旨：(緒言) 近年, 血清フリーテストステロン (Serum Free Testosterone : Se free T) の変動による情 緒や行動の変化が注目されている。一方, 唾液中テストステロン (Salivary Testosterone: Sa-T) は, ほ とんどが遊離した状態で存在することより Se free T との関連が示唆される. そこで今回, 我々は Sa-T を簡便な酵素免疫測定キットで測定し, その有用性を検討した.

（対象および方法）対象は 2004 年 1 月から 6 月までに当科で加療中の患者でボランティアを募り, 午 
前 6 時から午前 11 時までの間に血清と唾液の採取を同時に行った 76 例で男性 74 例, 女性 2 例, 年令は 28 才から 90 才 (平均 67.2 才 12.7 才）(以下，平均值士標準偏差）で中央值は 70 才であった。基礎疾患 は良性疾患 28 例と経過観察を含む悪性疾患 48 例で, このうち 16 例は前立腺癌に対し LH-RH アナログ によるホルモン療法が施行されていた. Sa-T, Se free Tおよび唾液サンプル中の血液混入についての測 定は, Salivary testosterone enzyme immunoassay kit（測定可能範囲 : 1.5 360pg/ml), Coat-A-Count free testosterone (測定可能範囲：0.15 50.0pg/ml), Blood contamination enzyme immunoassay kit (測 定可能範囲：0.2 10.0mg/dl）を用い，これらの測定值は二回測定值の平均值とした. 血清 Bioavailable testosterone（BT）は Liqiud Chromatography-Mass spectrometry/Mass spectrometry 法（測定可能範 囲：20.0pg/dl 以上）による実測值の測定を行った。これらの測定系の平均 Coefficient of variation は 15\% 以下であった.

（結果） 76 例の Se free T は 0.15 から $21 \mathrm{pg} / \mathrm{ml} （ 6.6 \pm 4.2 \mathrm{pg} / \mathrm{ml})$ で，その中央值は $7.0 \mathrm{pg} / \mathrm{ml}$ であり， 76 例中 10 例をランダムに抽出して BT との相関を検討したが，Se free T と BT には高い相関関係 $(\mathrm{r}=$ 0.964，P<0.01）を認めた。唾液 76 検体のうち血液の混入，測定限界值外であった 11 検体（14.5\%）を 除いた 65 検体の Sa-T は 32 から $360 \mathrm{pg} / \mathrm{ml}(176.8 \pm 96.6 \mathrm{pg} / \mathrm{ml})$ であり, その中央值は $168.0 \mathrm{pg} / \mathrm{ml}$ であっ た.

Se free $\mathrm{T}$ と Sa-T の 65 例の関連については有意な正の相関 $(\mathrm{r}=0.592, \mathrm{P}<0.01)$ がみられ，唾液テス トステロン測定值による血清フリーテストステロン值の予測が可能であった.

（結論）簡便な酵素免疫測定キットによる Sa-T の測定が可能であり，その值は Se free T と相関し SaTが生体内活性型テストステロンの簡易的な指標となり得ることが示された.

キーワード : 唾液, テストステロン, 酵素免疫測定

\section{緒 言}

血中トータルテストステロンのうち，その大部分は アルブミンや sex hormone binding globulin (SHBG) と結合し,残りの 1〜2\%はこれらに結合しないフリー テストステロンとして存在している1). 従来から血中 フリーテストステロン值と男性の行動・日常生活の状 態との関連 2 ( ) ，加齢や測定時間による值の変動が報 告され(5)6)，フリーテストステロンが生物学的活性を有 するテストステロンとして考えられてきた。近年では partial androgen deficiency in aging male (PADAM) がテストステロン低值による病態として認知され7), 血中フリーテストステロンとの関連も示唆されてい る.ささらに最近では体内テストステロン環境と前立腺 癌発生との関連も散見されるなど8), 今後体内テスト ステロンの生物学的活性の評価はますます重要になる ことが予想される.

一方, テストステロンは唾液や精囊液中にも存在す るが9)，唾液には SHBG がなく，そのほとんどが遊離 した状態で存在するため唾液中テストステロン值 (Salivary Testosterone: Sa-T) は血中フリーテストス テロン值を反映することが報告されており ${ }^{10) \sim 13) ， こ ~}$ れまでに小児領域における行動や成長について非侵襲 的でくり返し採取が可能な測定法としてその有用性が 散見されている ${ }^{1415)}$. 加えて Sa-T は血中フリーテス トステロンと比較し Biohazard としての危険性が少
ないという利点を持つ．本邦においても唾液中テスト ステロン測定の有用性は過去に散見されている が1617)，テストステロンの抽出など比較的煩雑な過程 が必要で現在までに日常の臨床に用いられることは少 なかった。

今回我々はこれらの点に着目し, Sa-T を簡便な酵素 免疫測定キットで測定し, 中高年齢を中心とした成人 に打ける Sa-T と血清フリーテストステロン（Se free T)との比較を行い, Sa-Tによって Se free T の予測が 可能か否かを検討し，その有用性を明らかにすること を本稿の目的とした。

\section{対象および方法}

2004 年 1 月から 6 月までに広島大学病院泌尿器科 で加療中の患者でボランティアを募り, 午前 6 時から 午前 11 時までの間に血清と唾液の採取を同時に行っ た 76 例を対象とした.全ての症例は他疾患の評価のた めに採血が予定された症例で, 検査終了後の血清の一 部と唾液を本研究に供与することに同意された，症例 の内訳は男性 74 例, 女性 2 例で年令は 28 から 90 才 (平均 $67.2 \pm 12.7$ 才, 中央值 70 才) (以下, 平均值 標準 偏差, 中央值) であり, その基礎疾患は良性疾患 28 例と経過観察を含む悪性疾患 48 例で，このうち 16 例 は前立腺癌に対し LH-RH アナログによるホルモン療 法が施行されていた。

唾液は採取直前に軽くうがい後, 数分間口腔内に唾 
Table 1 The results of all assays

\begin{tabular}{l|c|c|c|c}
\hline & Sa-T & Se free T & $\begin{array}{c}\text { Transferrin } \\
\text { concentration in } \\
\text { saliva }\end{array}$ & BT \\
\hline No. of Pts. & $65^{\#}$ & 76 & 76 & $10^{*}$ \\
Unit & $\mathrm{pg} / \mathrm{mL}$ & $\mathrm{pg} / \mathrm{mL}$ & $\mathrm{mg} / \mathrm{dL}$ & $\mathrm{pg} / \mathrm{mL}$ \\
Range & $32-360$ & $0.15-21.0$ & $0.08-6.6$ & $15.8-1,039.8$ \\
Median & 168.0 & 7.0 & 0.42 & 623.0 \\
\hline
\end{tabular}

Sa- $\mathrm{T}$ : Salivary testosterone

Se free $\mathrm{T}$ : Serum free testosterone

BT : Bioavailable testosterone

\# : Eleven out of 76 salivary samples (14.5\%) were disqualified as unsuitable.

* : Ten out of 76 serum samples were randomly chosen.

液をためて 50ml Conical Tube (Becton Dickinson Labware，NJ, USA）に採取後, $1.5 \mathrm{ml}$ Eppendolf tube (Greiner bio-one, Frickenhausen, Germany) に分 注, $-30^{\circ} \mathrm{C}$ で保存した. Sa-T の測定は, Salivary testosterone enzyme immunoassay kit（測定可能範囲： $1.5 \sim 360 \mathrm{pg} / \mathrm{ml}$, Salimetrics Inc., PA，USA）を用い, Se free Tの測定にはRIA 法による Coat-A-Count free testosterone（測定可能範囲：0.15 50.0pg/ml, Diagnostic Products Corporation, Los Angeles, USA）を用いた。喠液サンプル中の血液混入について， Blood contamination enzyme immunoassay kit（測 定 可能範囲：0.2 10.0mg/dl, Salimetrics）を用いて唾 液中トランスフェリン值を測定した。これらの測定值 は二重測定の平均値を採用した. 血清 Bioavailable testosterone (BT) については，アルブミンと結合してい るテストステロンとフリーテストステロンの総称と定 義し, Liqiud Chromatography-Mass spectrometry/ Mass spectrometry 法（測定可能範囲：20.0pg/dl 以 上）による実測值の測定を行ったそそれぞれの平均 coefficient of variation は 15\% 以下であった.

\section{結 果}

1）測定結果と唾液検体の選別（Table 1）

唾液検体については測定値に唾液以外の血液や細菌 などの口腔内環境が影響するため ${ }^{18}$, 血液混入, 測定 間值外の検体に対する希釈系列における検討によって 不適格検体の除外を行った。血液混入については唾液 中トランスフェリン值を 76 検体すべて測定した結果 は 0.08 から $6.6 \mathrm{mg} / \mathrm{dl}$ (平均值 $0.66 \pm 0.89 \mathrm{mg} / \mathrm{dl}$, 中央值 $0.42 \mathrm{mg} / \mathrm{dl}$ ) であったが，過去の報告 ${ }^{10)}$ から $1.2 \mathrm{mg} / \mathrm{dl}$ 以上を血液の混入ありと規定し， 7 検体を今回の検討 から除外した.また, 今回用いた測定キットでは Sa-T
の測定上限が $360 \mathrm{pg} / \mathrm{ml}$ であり，測定域值外の症例は 希釈系列にて再検したが，4検体はその希釈系列にお ける測定值に直線性が得られず計 11 検体（14.5\%）を 今回の検討から除外した. Sa-T については 76 検体の うち，この 11 検体を除く 65 検体 $(85.5 \%)$ を以後の検 討に用いることとした. Sa-T は 32 から $360 \mathrm{pg} / \mathrm{ml}$ (平 均值 $176.8 \pm 96.6 \mathrm{pg} / \mathrm{ml}$, 中央值 $168.0 \mathrm{pg} / \mathrm{ml}$ ) であり, その 65 例の年令は 40 から 86 才（平均值 $68.4 \pm 10.9$ 才, 中央值 70 才) で, 65 例のうち男性は 64 例で, こ のうち 16 例には LH-RH 投与が施行されていた.

血液検体では Se free T については 76 症例すべて の測定を行い，その測定值は 0.15 から $21 \mathrm{pg} / \mathrm{ml}$ (平均 值 $6.6 \pm 4.2 \mathrm{pg} / \mathrm{ml}$, 中央值 $7.0 \mathrm{pg} / \mathrm{ml}$ ) であった. BT については, 76 症例のうち 10 例を無作為に抽出し測 定を行ったが，この中には女性 1 例および前立腺癌に 対する内分泌療法施行例 2 例が含まれていた.

2) Se free Tと BT の相関 (Fig. 1)

76 例中, BT を測定した 10 例を対象として Se free $\mathrm{T}$ と BT との相関を検討したが, Se free T と BT に強 い相関（ $\mathrm{r}=0.964 ， \mathrm{P}<0.01)$ を認めた.

3）男性における加齢と Se free Tおよび Sa-T の変 動 (Fig. 2)

男性 74 例のうち 16 例は内分泌療法を受けており, ホルモン環境が治療によって修飾されているため, こ れらを除いた 58 例について加齢とSe free T (Fig. 2A) との相関を検討した. また, この 58 例の唾液検体のう ち 11 例は前述の不適格例であったため 47 例を対象と し，年令と Sa-T (Fig. 2B) との相関を検討した. Se free $\mathrm{T}$ は加齢との負の相関 $(\mathrm{r}=-0.622, \mathrm{P}<0.01)$ がみ られ, Sa-T についても弱い負の相関 $(\mathrm{r}=-0.330, \mathrm{P}<$ 0.05）が見られた. 
4） Se free T と Sa-T の相関（Fig. 3）

不適格として除外した唾液 11 検体の症例を除く 65 例の Se free Tと Sa-Tについて相関を検討した. 65 例のうち男性は 64 例で, そのうち 16 例には内分泌療 法が施行されていた. Se free T と Sa-T には有意な正

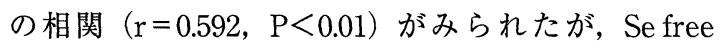

Fig. 1 Correlation between bioavailable testosterone (BT) and serum free testosterone (Se free T)

$\bigcirc$ : Male patients except for those receiving hormone therapy

: Male patients receiving hormone therapy and females

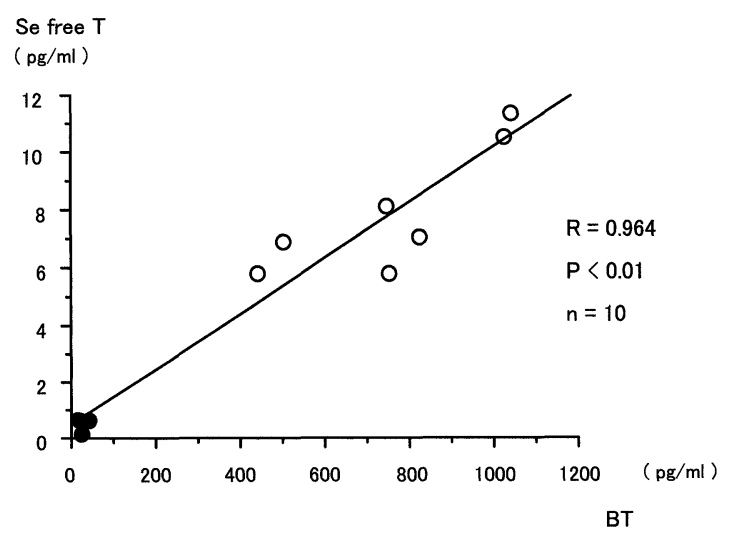

$\mathrm{T}$ と Sa-Tには比例関係はみられなかった。

5）Sa-Tによる Se free T の予測（Fig. 4）

$\mathrm{Sa}-\mathrm{T}$ を濃度別に低值群 ( $120 \mathrm{pg} / \mathrm{ml}$ 未満), 中間群 $(120$ 以上 $240 \mathrm{pg} / \mathrm{ml}$ 未満), 高值群 $(240 \mathrm{pg} / \mathrm{ml}$ 以上 360 $\mathrm{pg} / \mathrm{ml}$ 以下）の3 群に分けて, 各群における Se free Tを 95\% 信頼区間で示した.いずれの群間にも有意差 がみられ，Sa-Tによる Se free T の予測が可能であっ た.

\section{考察}

今回の結果より, 酵素免疫測定キットによって Sa$\mathrm{T}$ の簡便な測定が可能であり，その值は Se free Tに 相関し, Se free T の予測が可能であることが示され た.

今回用いた䤃素を標識する酵素免疫測定法は一般的 にはラジオイムノアッセイ法に比べて標識物質が安定 で，長期の保存が可能，アイソトープを使用しないた め測定に特別な施設を必要としないなどの利点があ り，抗原抗体反応に適した標識酵素の測定系を組みや すく, 検出系の変化によって高感度化が比較的容易で あるなどの特徴をもっている.

唾液検体における Sa-T の測定では検体の取り扱い が特に重要であり, その採取方法, 血液混入, 保存な どがあげられる。唾液の採取に際し綿の使用による測 定值の上昇 ${ }^{11)}$ ，ガムの咀嚼による唾液の分泌採取で は, 分泌開始からの時間によって濃度が変化すること

Fig. 2 Correlation between age and testosterone level in males, excluding patients receiving hormone therapy

(A) : Age vs. serum free testosterone (Se free T)

(B) : Age vs. salivary testosterone (Sa-T)

(A)

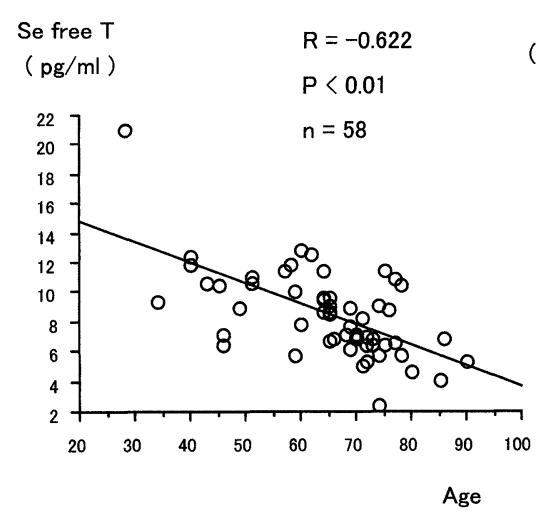

( years old)
(B)

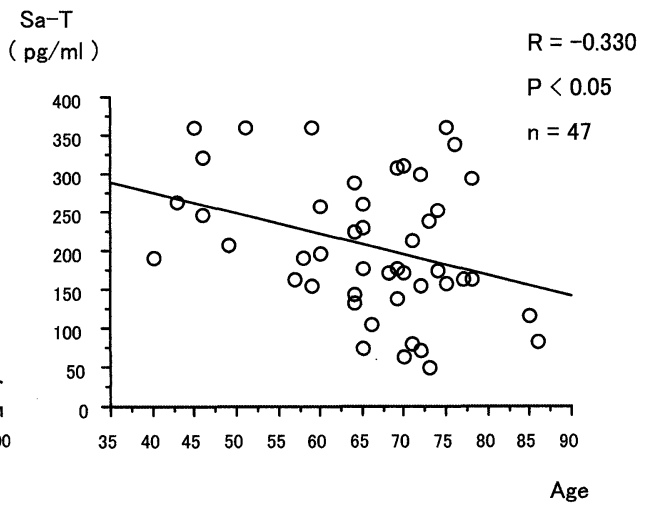

( years old) 
Fig. 3 Correlation between serum free testosterone (Se free $\mathrm{T}$ ) and salivary testosterone (Sa-T) $\bigcirc$ : Male patients except for those receiving hormone therapy

: Male patients receiving hormone therapy and females

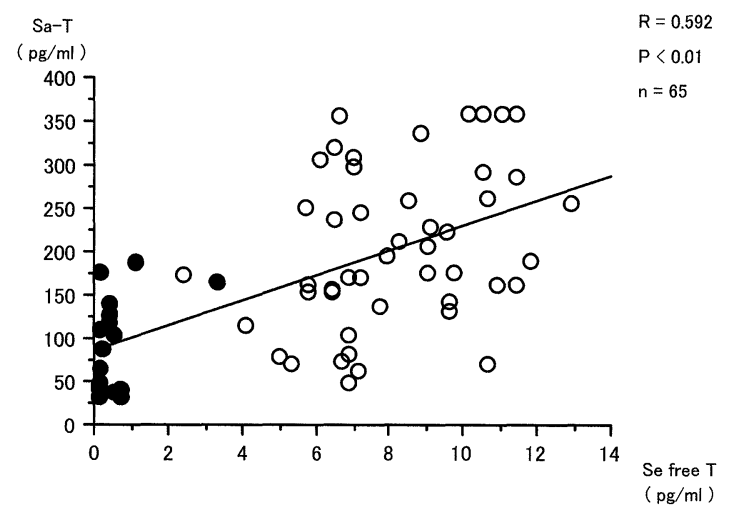

が知られている ${ }^{10)}$.このためわれわれは, 何の器具も 用いず軽くうがいをした後に唾液を口腔内に貯留させ 数分後に採取する方法を用いた，検体については肉眼 的に明らかな血液混入はなかったが，今回の対象が他 疾患の治療目的に来院したボランティアであり，高歯 者が多い背景から義歯装着による微少な血液混入の可 能性は高く，唾液中トランスフェリンの測定によって 7 例 $(9.2 \%)$ が除外された。保存では，採取した唾液は 可及的早期に $-80^{\circ} \mathrm{C}$ 以下の超低温での冷蔵が望まし いが18)，これは一部の研究施設に限られる。われわれ は，実践的な臨床研究としてこの研究を位置付け，冷 凍保存は $-30^{\circ} \mathrm{C}$ で行った. 保存から測定までの期間は すべての検体で 6 力月以内であったが， $-40^{\circ} \mathrm{C} 6$ 力月 間の検体保存により $6.5 \%$ 測定值が減少するとの報 告 ${ }^{18)} も$ みられ, 保存期間は可及的短期間にする必要が ある. 一方で，口腔内の細菌の状況によっては，Sa$\mathrm{T}$ の著しく高い測定值が検出され， $4{ }^{\circ} \mathrm{C}$ での検体保存 では Sa-T は時間とともに指数関数的に増加すること が報告されている ${ }^{18)}$.これは細菌増殖による抗体との 結合阻害や加水分解されたテストステロンを免疫反応 で捉えていることに起因すると考えられている.今回， Se free T と Sa-T とに完全な比例の関係が得られず Se free Tが低值にも関わらず Sa-T が比較的高值で あった検体や， $360 \mathrm{pg} / \mathrm{ml}$ を超えた検体で希釈系に よってその測定值に再現性が得られず除外した検体が
Fig. 4 Estimated serum free testosterone (Se free $\mathrm{T}$ ) value based on the salivary testosterone (Sa-T) level * : Error bars show 95\% confidence interval.

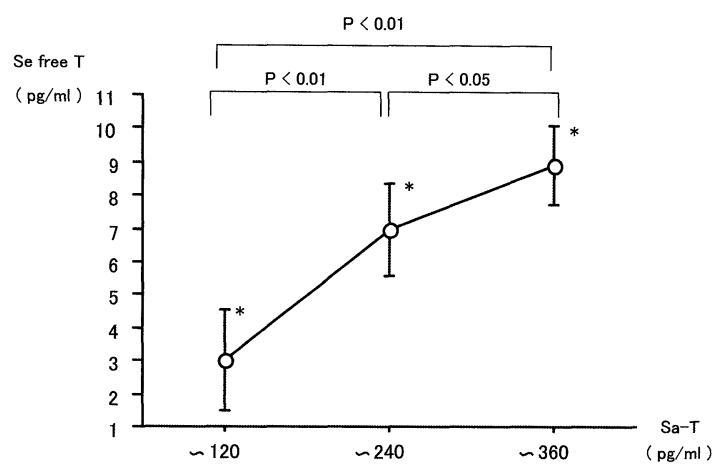

4 検体 $(5.3 \%)$ みられたが，このような唾液中の細菌の 存在が原因の一つかも知れない.これらの問題点の解 決には，採取した唾液の可及的速やかな保存処理と測 定が今後の課題である.

従来から血中フリーテストステロン值と，加齢や測 定時間による值の変動が報告されているが(3) 6)，今回 の検討においても同様に加齢とともに, Se free T は有 意に減少していた。一般的に加齢に伴う Se free T の 低下とこれに呼応するかのような PADAM の病態出 現はSe free T が生物学的活性の役割を担うことを示 唆する. 現在, 体内テストステロンの生物学的活性を より正確に示すものとして, bioavailable testosterone が期待されているが(9)，その実測值の測定については 現時点では一部の研究施設でのみ可能であり ${ }^{20)}$, 今回 は 10 検体のみを無作為に抽出し BT の測定を試みた. その結果 Se free Tと BT がよく相関したことから, Se free Tの測定值を生物学的な活性を有するテスト ステロンとして簡易的に用いることが可能ではないか と考えた

一方，唾液中テストステロン值測定の有用性は小児 において過去に散見されているが(4)15), 今回の結果か ら中高年齢を中心とした成人においても Sa-T が生体 内活性型テストステロンの簡易な指標となり得る可能 性を示唆する。しかしながら前述したように，唾液の 分泌速度や細菌など口腔内の環境による測定值の影響 は少なくないため，あくまでも大まかな指標として捉 えることが必要であろう. 本研究では Fig. 4 に示した ように Sa-Tから Se free Tを予測するために Sa-T を，低值群 $(120 \mathrm{pg} / \mathrm{ml}$ 末満)，中間群 (120 以上 240 
$\mathrm{pg} / \mathrm{ml}$ 未満), 高值群 $(240 \mathrm{pg} / \mathrm{ml}$ 以上）の 3 群に分類 し検討を行ったが, 中間群における Se free T の予測 值は近年報告された 20 歳代から 70 歳代の日本人の血 清フリーテストステロン基準下限值の $4.5 \sim 8.5 \mathrm{pg} / \mathrm{ml}$ にほぼ一致しており ${ }^{21)}$, 今後PADAMの補助的診断 や前立腺癌患者の予後予測として使用することも可能 かもしれない. 今回の検討での患者プロファイルは症 例全員が泌尿器科に何らかの疾患で治療中の患者であ ク，健常人とのバイアスが存在するが，これらの Sa$\mathrm{T}$ が生体内活性型テストステロンの簡易な指標となり 得る可能性が示されたことは，今後唾液テストステロ ン測定の臨床の場での応用が期待される.

(本稿の要旨は第 23 回日本アンドロロジー学会総会にお いて発表した.）

謝辞：本研究に際し, 多大な御助力を頂きました福山臨 床検査センター研究開発部, 木本真史氏に深謝いたします。 文献

1) Vermeulen, A. : Diagnosis of partial androgen deficiency in the aging male. Ann. Endocrinol., 64, $109-114,2003$

2) Hirschenhauser, K., Frigerio, D., Grammer, K. and Manussons, M.S. : Monthly patterns of testosterone and behavior in prospective fathers. Horm. Behav., 42, 172-181, 2002.

3) Booth, A., Johnson, D.R. and Granger, D.A.: Testosterone and men's depression : the role of social behavior. J. Health Soc. Behav., 40, 130-140, 1999.

4) Krause, W., Mueller, U. and Mazur, A. : Measurement of steroid levels in saliva in a populationbased survey of lifestyle, medical conditions, marriage, sex life and hormone status in aging men : a feasibility study. Aging Male, 5, 203-215, 2002.

5) Ellison, P.T., Bribiescas, R.G., Bentley, G.R., Campbell, B.C., Lipson, S.F., Panter-Brick, C. and Hill, K. : Population variation in age-related decline in male salivary testosterone. Hum. Reprod., 17, 32513253, 2002.

6) Dabbs, J.M. : Salivary testosterone measurements : reliability across hours, days, and weeks. Physiol. Behav., 48, 83-86, 1990.

7) Morales, A. and Lunenfeld, B. : International Society for the Study of the Aging Male. Investigation, treatment and monitoring of late-onset hypogonadism in males. Official recommendation of ISSAM. International Society for the Study of the Aging Male. Aging Male, 5, 74-86, 2002.

8) Thompson, I.M., Goodman, P.J., Tangen, C.M., Lucia, M.S., Miller, G.J., Ford, L.G., Lieber, M.M.,
Cespedes, R.D., Atkins, J.N., Lippman, S.M., Carlin, S.M., Ryan, A., Szczepanek, C.M., Crowley, J.J. and Coltman, C.A. : The Influence of Finasteride on the Development of Prostate Cancer. N. Eng. J. Med., 349, 215-224, 2003.

9) Sannikka, E., Terho, P., Suominen, J. and Santti, R.: Testosterone concentration in human seminal plasma and saliva and its correlation with nonprotein-bound and total testosterone levels in serum. Int. J. Androl., 6, 319-330, 1983.

10) Shirtcliff, E.A., Granger, D.A. and Likos, A.: Gender differences in the validity of testosterone measured in saliva by immunoassay. Horm. Behav., 42, 62-69, 2002.

11) Shirtcliff, E.A., Granger, D.A., Schwartz, E. and Curren, M.J. : Use of salivary biomarkers in biobehavioral research : cotton-based sample collection methods can interfere with salivary immunoassay results. Psychoneuroendocrinology, 26, 165-173, 2001.

12) Wang, C., Plymate, S., Nieschlag, E. and Paulsen, C.A. : Salivary testosterone in men : further evidence of a direct correlation with free serum testosterone. J. Clin. Endocrinol. Metab., 53, 10211024, 1981.

13) Johnson, S.G., Joplin, G.F. and Burrin, J.M. : Direct assay for testosterone in saliva : relationship with a direct serum free testosterone assay. Clin. Chim. Acta., 163, 309-318, 1987.

14) Granger, D.A., Schwartz, E.B., Booth, A. and Arents, M. : Salivary testosterone determination in studies of child health and development. Horm. Behav., 35, 18-27, 1999.

15) Ohzeki, T., Manella, B., Gubelin-De Campo, C. and Zachmann, M. : Salivary testosterone concentrations in prepubertal and pubertal males : comparison with total and free plasma testosterone. Horm. Res., 36, 235-237, 1991.

16）梅原次男, 熊本悦明, 三熊直人, 伊藤直樹, 南部 明民, 新田俊一：思春期男子に於ける睡液中 testosterone 值の検討. 日内分泌会誌，67, 230-238, 1991.

17）郝 金瑞, 伊藤直樹, 新田俊一, 黒畑敏江, 塚本泰 司, 熊本悦明, 梅原次男：唾液中テストステロン濃 度の加齢に伴う変化についての検討. 泌尿紀要, 40, 807-811, 1994.

18) Granger, D.A., Shirtcliffd, E.A., Boothc, A., Kivlighana, K.T. and Schwartz, E.B.: The "trouble" with salivary testosterone. Psychoneuroendocrinology, 26, 165-173, 2004.

19) Tsujimura, A., Matsumiya, K., Matsuoka, Y., 
616

Yakahashi, T., Koga, M., Iwasa, A., Takeyama, M. and Okuyama, A.: Bioavailable testosterone with age and erectile dysfunction. J. Urol., 170, 23452347, 2003.

20）本間誠次郎，川辺勝弘，見澤三枝子，奥山光伸， 熊谷幸博, 岡崎 豊: 血中バイオアベイラブル Testosterone の測定法. ホルモンと臨床, 52, $829-844,2004$.
21）岩本晃明，柳瀬敏彦，高 栄哲，堀江 均，馬場 克幸, 並木幹夫, 名和田 新：日本人成人男子の総 テストステロン, 遊離テストステロンの基準值の 設定. 日泌尿会誌, 95, 751-760, 2004.

(2004 年 10 月 4 日受付, 2005 年 2 月 15 日受理) 